\title{
Introduction
}

\section{Museums as arenas for the production and circulation of knowledge on Sámi cultures, societies and identities}

\author{
Cathrine Baglo, Jukka Nyyssönen \& Rossella Ragazzi
}

Museums have been central sites for production of knowledge on the Sámi. ${ }^{1}$ Being equipped to disseminate this knowledge in novel ways, museums have a special role and responsibility towards, both, the majority societies and Sámi societies alike. This publication examines how the relationship between society and the production and dissemination of knowledge on Sámi cultures has changed in the context of Nordic museums. A more ambitious scope is to see whether and how these changes have had an impact on the societal discourses about the Sámi and on the representation and construction of Sámi museology. The aim is to offer a critical view on the history of "Lappology" up to contemporary research and representation of the Sámi as it has unfolded in Scandinavia, and in part also northern Russia.

The point of departure is that the scholarly production of knowledge and society share a complex interdependence. In museums in general, the voice of the Sámi has grown from a muted research object to a strong researching subject with a morally compelling voice. The old authorities of Sámi research collecting and mouth-piecing the Sámi have been transformed into objects of deconstructive research. As a result of this democratization, museums have become sites of more equal encounters and an ethno-political platform in which the Sámi build their identities and voice their demands. We are particularly interested in exploring how different discourses, and institutional and societal contexts, in this case museums or exhibition arenas, have had impact on and continue to impact the production of knowledge on Sámi cultures, histories and identities across time.

The contributors are museologists, historians, anthropologists, archaeologists and cultural studies scholars with experience from working in and writing about museums and their practices. They are all from countries with native Sámi populations (Norway, Finland, Sweden, Russia), and they have specialised in various fields of study and issues relating to the Sámi. The contributors are part of the Nordic research project "Societal Dimensions of Sámi Research", financed by the Norwegian Research Council. $^{2}$

This publication has ten articles organised according to a chronological historical timeline.

In her article about a double set of Sámi artefacts collected in Norway in the 1850s, Silje Opdahl Mathisen offers a critical view on the establishment of a Sámi collection at the Museum of Ethnography in Oslo, as well as notions of ethnicity and race. While one set remained in Oslo the other was to be exhibited at the Crystal Palace exhibition in London. 
Moreover, the author demonstrates how parts of the collection have roots in one of the darkest chapters in Sámi-Norwegian history the Kautokeino uprising.

Cathrine Baglo explores the connection between two early industrial expositions, Norwegian assimilation policies towards the Sámi in the last part of the nineteenth century and what she argues is the disappearance of the Sea Sámi as a cultural display category. According to a classic study conducted in a Sea Sámi community, in 1971, all signs of a Sámi past were associated with the social stigma and shame of the inhabitants. It is the contours of this path that we see sign of in the Tromsø expositions, Baglo argues.

Eeva-Kristiina Harlin and Veli-Pekka Lehtola examine the Sámi collections in the National Museum of Finland, which were provided by the Finnish Lappologist T. I. Itkonen from 1912 to 1927 . More than ninety percent of his collections came from the Skolt Sámi area. The objects received a fair amount of attention at the National Museum, but were subjected to the almost compulsory representation of reindeer herding. Today, Itkonen's collection has gained new meaning for the Skolt Sámi community due to the repatriation of the entire Sámi collection of the National Museum to the Siida Sámi Museum, as the article demonstrates.

Dikka Storm looks at the roles of the Ethnographic Museum in Oslo and Tromsø Museum in relation to the production of Sámi research from the end of the nineteenth century until the post-war years. By emphasising the academic development of particular individuals and the development of professional networks, she calls attention to the establishment and effects of a specific research strategy. Moreover, she argues that the ethnographer Ørnulv Vorren and Tromsø Museum became important contributors to the advancement of
Sámi research and the bolstering of the Sámi ethno-political movement.

Veli-Pekka Lehtola challenges the perception of the muted Sámi research object in his article on the life and career of Johan Nuorgam, a Sámi expert and future museum expert. In the 1930s, he worked as a custodian and presenter at the "Lapp section" of the open-air museum at Seurasaari in Helsinki, and during the period 1959-63 he brought this knowledge home and established the first Sámi museum in Inari in Finland. Lehtola analyses Nuorgam's life in terms of James Clifford's concept of the "Squanto", a cultural broker with complex relations to both "outsiders" and his own community.

Eva Silvén offers an overview of Sámi research and collecting at the Nordic Museum in Stockholm with focus on the curator Ernst Manker and the period 1930-1970. The author focuses on the friction between the potentially essentialising and emancipatory effects of Manker's work in relation to its societal impact. The cultural heritage created by Manker at the Nordic Museum (object collections, photographs, media, scientific research and popular travelogues texts) was definitely based on an outsider's view of the Sámi, but in ways that today may lead to decolonising and reappropriating it.

Trude Fonneland retraces the social and political consequences of the exhibition Samekulturen (The Sámi Culture, 1973), at Tromsø University Museum, which still serves as an arena forty years on for the dissemination of Sámi culture to visitors. By contextualising the production of Samekulturen and discussing its genesis, particularly in relation to the later exhibition Sápmi - en nasjon blir til (Sápmi becoming a nation), the chapter argues that Samekulturen has regained validity as a social actor. The co-existence of the two exhibitions opens for new insights regarding Sámi identities 
and the production of knowledge and heritage, the author claims.

Adopting a longer time perspective on Tromsø University Museum, Rossella Ragazzi and Giacomo Nerici focus on the set up, reception and social scientific discursive fields that have informed two exhibitions on the Sámi as curated over time by Tromsø University Museum: Sápmi - en nasjon blir til (2000) and Sámi Stories (2014), employing a recursive comparison with the aforementioned Samekulturen (1973). The authors individuate a set of discursive paradigms that have influenced scholars, visitors and curators interacting at the museum. The concept of heritage is here seen as situated, negotiated and processual. The authors look at how certain aspects of Sámi material and immaterial heritage have been constructed, performed and narrated to articulate different discursive registers concerning materiality, ethnic identity and cultural belonging.

Tiina Äikäs explores the presentations of Sámi religion in museums and exhibitions in northern Finland: Siida The National Museum of the Finnish Sámi in Inari, Arktikum in Rovaniemi, the Museum of Northern Ostrobothnia in Oulu, and the Samiland exhibition in Levi. The chapter analyses the themes and histories of these presentations, and discusses them in relation to the long history of displaying Sámi religion in museums in Finland. It is argued that Sámi religion is commonly relegated to the past and presented as disconnected from Christianity. Even so, contemporary exhibitions of Sámi religion hold the potential to renew, comment on and question old presentations.

Monica Grini explores how Sámi culture is presented in various museums in Oslo. Sámi matters are predominantly articulated as "culture" in the anthropological sense of the museumscape she sets out to explore.
The question of how the old binary of "art" and "ethnographica" is still predicated in the museums of Norway's capital is crucial here. The art museums show "European" and "Norwegian" art, and the Ethnographic Museums display the craft of non-Western cultures and in this case Sámi duodji, sometimes even subsumed under the homogenising concept of Arctic culture. This absence of seeing Sámi works, topics and artists from a "national imagery" perspective reinforces the grand narrative of Norway as a monocultural nation.

Curating, collecting, conserving and circulating knowledge on the Sámi is increasingly becoming a dialogical process, which reveals the role of the museums as social actors after the paradigm change and the democratization of Sámi research. The relationship of research, museums and societies is also dialogical. Museums participate in the co-articulation of the societal discourses of Sáminess with their knowledge production, and are affected by the same discourses. The dialogue, multiplying in voices, will continue.

\section{Cathrine Baglo, Jukka Nyyssönen \& Rossella Ragazzi}

\section{Notes}

1. We apply the term "Sámi" in most of the articles since it is the term chosen and used in official documents by Sámi Parliament in Norway. The term is considered to come close to the pronunciation of the Sámi languages. The choice is a compromise for the sake of editorial consistency. The authors address the issue of ethnonym, according to their own focus and needs, but the publication language dictates the choice of the ethnonym in more general references to the Sámi culture, society etc.

2. Project number 270629. 